\title{
PAULA, Márcio Gimenes de. Subjetividade e objetividade em Kierkegaard. São Paulo: Annablume, 2009.
}

Marieta Moura de Pinho*

Márcio Gimenes de Paula inicia este livro analisando a subjetividade kierkegaardiana entre o enigma socrático e o mistério cristão. Ele aborda o conflito entre objetividade e subjetividade, relacionando-o com a figura de Sócrates, que representa a ironia, e com a figura de Cristo, que é a profunda imagem do mistério. O livro organiza-se em forma de um diálogo kierkegaardiano com Lessing (1729-1781) e Feuerbach (18041872), em um primeiro momento.

Lessing, visto como um dos pilares do iluminismo alemão, é um filósofo que admira autores deístas. Para ele, a busca da verdade deve ser feita a partir dos pensadores gregos, e a revelação já está presente nos primórdios da filosofia. O diálogo com esse autor se dá a partir da carta Sobre a demonstração em espírito e força, que é uma resposta de Lessing a contestações de Johann Daniel Schumann. Nela, o filósofo assinala a importância de se ler tanto a tradição cristã quanto a revelação, trabalhando em conjunto a filosofia clássica e a tradição bíblica (judaico-cristã).

O diálogo com Feuerbach é feito a partir de A essência do cristianismo (1841), um texto em que o pensador alemão usa o método histórico-filosófico de análise. Feuerbach considera a religião não como uma quimera, um nada, mas como uma ilusão. Suas teses antecipam as de Freud. Na religião, o simbólico refere-se a Deus, no entanto, Feuerbach deseja fazer com que esse simbólico se refira ao homem e, sendo assim, a religião seria antropologia.

\footnotetext{
* Mestre em Ciências da Religião, PPGCR (2008-2009)Tem experiência na área de Letras, com ênfase em Língua Portuguesa, atuando principalmente nos seguintes temas: Educação, Ensino Religioso,Teologia Pastoral e Ciências da Religião.
} 
Segundo Gimenes, Kierkegaard foi um leitor de Lessing e Feuerbach, tendo sido influenciado por ambos. Após ler A essência do cristianismo, em 1844, o filósofo dinamarquês afirma que Feuerbach não critica o cristianismo, mas a cristandade. O PostScriptum final não-científico às migalhas filosóficas (1846) relata dois tipos de religiosidade - a religiosidade A, mais estética, e a B, mais patética - que representam a influência do pensador alemão, uma importante figura na trama dos conceitos kierkegardianos.

Gimenes acentua a singularidade da leitura do pensamento socrático feita por Kierkegaard, que apresenta Sócrates como irônico, aquele que chega primeiro à ideia da dialética, mas não desenvolve a dialética da ideia e aquele cuja semelhança com Cristo está exatamente em sua dessemelhança. Sócrates é um crítico das instituições e do próprio modo de pensar grego. Ele servirá para ilustrar, no pensamento kierkegaardiano, a distinção entre os estádios da existência humana: estético, ético e religioso. Na visão hegeliana, Sócrates é uma figura que serve para ressaltar a subjetividade, o homem como propósito, a subjetividade infinita. Para o pensador alemão, há em Sócrates três importantes aspectos: a ironia, a maiêutica e a consciência de si.

A estrutura da obra kierkegaardiana é analisada através dos pseudônimos Johannes de Silentio, Clímacus e Anti-Clímacus. Silentio, autor de Temor e tremor (1843), ultrapassa, com a descrição poética, a rigidez da ética. Embora essa obra aborde o tema do paradoxo da fé, Silentio é apenas um poeta que canta as belezas da fé, como outros já cantaram o amor.

Johannes Clímacus, em Migalhas filosóficas, ressalta a diferença entre a concepção socrática da verdade e a concepção cristã, na qual a importância está no instante em que o discípulo opta por seguir o mestre, que é, em si, a verdade e a condição para se compreender a verdade. O projeto de Clímacus está relacionado com o paradoxo da fé. E a fé não é apenas dogmática e doutrinária, mas eterna e existencial.

Já Anti-Climacus, autor de A doença mortal e Prática do cristianismo, é importante para estudar o cristianismo em Kierkegaard. Para ele, o cristão é o único que conhece a doença mortal superando os males menores. Ela é uma doença do espírito, uma doença do eu. Segundo Anti-Clímacus, não é raro encontrar alguém desesperado, mas sim encontrar quem não o seja. 
Gimenes chama a atenção ainda para a obra Discursos edificantes (1843/44), que nos leva a compreender melhor o panorama do cristianismo em Kiekegaard. Interessante e curiosa é a nota explicativa que ele acrescenta em todos os volumes: "são discursos, pois seu autor não possui autoridade para pregar"; e são também discursos destinados ao seu leitor "único e individual". Primeiro, ele não é ministro ordenado, por isso não está autorizado a pregar, e segundo, seu discurso será sempre dirigido ao homem individual, o que exprime sua posição filosófica.

O importante deste livro de Gimenes, para além das interessantes informações sobre a subjetividade e objetividade, é a compreensão do corpus kierkegaardiano. Em O Ponto de vista explicativo da minha obra como escritor, publicada postumamente, Kierkegaard esclarece o caráter de duplicidade: ser a sua obra religiosa desde o princípio e ainda estética no final. O objetivo de Kierkegaard foi sempre a temática do tornar-se cristão, e sua meta o indivíduo. A maiêutica socrática e a pseudonímica foram estratégias para atingir o seu objetivo, que é, em uma linguagem singular - a comunicação indireta - declarar não ser cristão. 